\title{
PERBEDAAN ANTARA TINGGI BADAN BERDASARKAN PANJANG ULNA DENGAN TINGGI BADAN AKTUAL DEWASA MUDA DI KOTA SEMARANG
}

\author{
Kholishah Thahriana Sutriani, Muflihah Isnawati ${ }^{*}$ \\ Program Studi Ilmu Gizi Fakultas Kedokteran Universitas Diponegoro \\ Jl.Dr.Sutomo No.18, Semarang, Telp (024) 8453708, Email : gizifk@undip.ac.id
}

\begin{abstract}
Background: Nowadays, there is still a problem to assess nutritional status in hospitaly patient. Mainly, the stature measurement was difficult because of patient condition. Stature can be estimated by ulna length. Ulna length has been proven can be used to estimate stature in United States, Europe, India and Thailand.

Objective: to analyze the differences stature results based on the ulna length with the actual stature of young adult in Semarang.

Methods: This is a cross sectional study, involving 103 subjects, consist of 48 men and 55 women with age range 19-29 years old. Data collected were characteristic of subject, actual stature, and ulna length. Estimation stature calculated using three stature formulas from previous study.

Results: mean of actual stature for men 167,9 cm and women 156,9 cm. Mean of stature estimation from Ilayperuma et al, Thummar et al, dan Pureepatpong et al were for men 168,24 cm, 166,28 cm, and 167,61 cm; and for women $157,77 \mathrm{~cm}, 153,79 \mathrm{~cm}$, and 155,88 cm. The mean difference between actual stature with estimation stature from Ilayperuma et al, Thummar et al, dan Pureepatpong et al were for men 0,35 cm, -1,62 cm, and -0,28 $\mathrm{cm}$; and for women $0,86 \mathrm{~cm},-3,12 \mathrm{~cm}$, dan $-0,28 \mathrm{~cm}$. The most difference between actual stature and estimation stature was from Thummar et al which is for men $-1,62 \mathrm{~cm}$ and for women $-3,12 \mathrm{~cm}$. The measurement of actual stature in men and women were no difference $(p>0,05)$ between the actual stature and the estimated stature of the ulna length from formulas Ilayperuma et al and Pureepatpong et al and there were difference $(p<0,05)$ in men and women between the actual stature and the estimated stature of the ulna length from formula Thummar et al. This study resulted new regression linier formula, men $=76,053+3,405 x$ ulna length and women $=81,927+3,034 x$ ulna length.

Conclusion: Formula Ilayperuma et al (men= 97,252 + 2,645 x ulna lenght and women= 68,777 + 3,536 x ulna lenght) and Pureepatpong et al (men= 64,605 + 3,8089 $x$ ulna lenght and women $=66,377+3,5796 x$ ulna lenght) can be applied to estimate a stature in Semarang.
\end{abstract}

Keywords: estimation of stature; anthropometry; ulna bone; Semarang

\section{ABSTRAK}

Latar Belakang: Penilaian status gizi pasien rawat inap di rumah sakit di Indonesia saat ini masih sulit dilakukan karena kondisi pasien yang harus berbaring di tempat tidur. Pengukuran antropometri menjadi bagian dari penilaian status gizi sebagai dasar perhitungan kebutuhan gizi pasien dan untuk menentukan risiko timbulnya masalah gizi. Penelitian di Amerika, Eropa, India dan Thailand menunjukkan bahwa panjang tulang ulna telah terbukti reliabel dan presisi dalam memprediksi tinggi badan seseorang.

Tujuan: Penelitian ini bertujuan untuk menganalisis perbedaan hasil tinggi badan berdasarkan panjang tulang ulna dengan tinggi badan aktual pada pria dan wanita dewasa di Kota Semarang.

Metode: Penelitian ini merupakan penelitian cross sectional. Jumlah sampel dalam penelitian ini adalah 103 orang yang terdiri dari 55 wanita dan 48 usia 19 - 29 tahun. Data yang diambil yaitu data karakteristik subjek, tinggi badan dan panjang ulna. Subjek penelitian diambil secara consequtive sample yang diberikan informed consent secara verbal. Data panjang ulna subjek kemudian dimasukkan dalam tiga formula estimasi tinggi badan dari penelitian sebelumnya.

Hasil: rerata tinggi badan aktual pria $167,9 \mathrm{~cm}$ dan wanita $156,9 \mathrm{~cm}$. Rerata estimasi tinggi badan rumus Ilayperuma et al, Thummar et al, dan Pureepatpong et al berturut - turut adalah untuk pria 168,24 cm, 166,28 cm, dan 167,61 cm; dan untuk wanita 157,77 cm, 153,79 cm, dan 155,88 cm. Selisih tinggi badan aktual dengan estimasi tinggi badan berturut-turut adalah untuk pria 0,35 cm, $-1,62 \mathrm{~cm}$, dan -0,28 cm; dan wanita 0,86 cm, $-3,12$ $\mathrm{cm}$, dan -0,28 cm. Selisih terbesar terdapat pada rumus estimasi Thummar et al yaitu pada pria $-1,62 \mathrm{~cm}$ dan pada wanita $-3,12 \mathrm{~cm}$. Tidak ada perbedaan antara tinggi badan aktual dengan estimasi tinggi badan dari panjang ulna rumus Ilayperuma et al dan Pureepatpong et al pada pria dan wanita $(p>0,05)$ dan ada perbedaan antara tinggi badan aktual dengan estimasi tinggi badan dari panjang ulna rumus Thummar et al pada pria dan wanita $(p<0,05)$. Penelitian ini menghasilkan formula regresi linier dari tinggi badan dan panjang ulna subjek, yaitu untuk pria = $76,053+3,405 x$ ulna lengan kiri; untuk wanita $=81,927+3,034 x$ ulna lengan kiri.

${ }^{*}$ Penulis Penanggungjawab 
Kesimpulan: rumus Ilayperuma et al (pria $=97,252+2,645$ x panjang ulna dan wanita $=68,777+3,536$ x panjang ulna) dan Pureepatpong et al (pria $=64,605+3,8089 x$ panjang ulna dan wanita $=66,377+3,5796 x$ panjang ulna) dapat diterapkan di Semarang.

Kata kunci: estimasi tinggi badan; antropometri; tulang ulna; Semarang

\section{PENDAHULUAN}

Penilaian status gizi pasien rawat inap di rumah sakit di Indonesia saat ini masih sulit dilakukan karena kondisi pasien yang harus berbaring di tempat tidur. Pengukuran antropometri menjadi bagian dari penilaian status gizi sebagai dasar perhitungan kebutuhan gizi pasien dan untuk menentukan risiko timbulnya masalah gizi. ${ }^{1}$ Penelitian yang dilakukan di Belgia dan Australia menyatakan bahwa pengukuran berat badan dan tinggi badan pada pasien rawat inap di rumah sakit yang dilakukan oleh perawat tidak akurat. Satu dari empat perawat yang berpartisipasi salah mengklasifikasikan pasien dalam kategori indeks massa tubuh, pengukuran berat badan menggunakan calibrated weight chair (SECA Model 954 13091003, kapasitas 200 kg dengan ketelitian $0,1 \mathrm{~kg}$ ) dan tinggi badan menggunakan stadiometer, yang dipasang di weight chair (SECA model 221, kapasitas $230 \mathrm{~cm}$ dan dengan ketelitian $0,5 \mathrm{~cm})$. Perbedaan antara hasil pengukuran tinggi badan oleh perawat dengan tinggi badan aktual adalah $-1,2$ sampai $+3 \mathrm{~cm}^{2,3}$

Pengukuran tinggi badan dapat dilakukan dengan menanyakan langsung kepada pasien, mengukur langsung ditempat dengan posisi berdiri tegak, jika tidak dapat berdiri dapat diukur dengan rentang tangan atau tinggi lutut. Pengukuran rentang tangan dan tinggi lutut dirasa sulit dilakukan, kurang tepat menggambarkan tinggi badan yang sebenarnya dan ketidakpraktisan alat yang digunakan. Apabila pasien mengalami kelainan pada sendi lututnya atau ketidakmampuan merentangkan tangan secara lurus maka pengukuran sulit atau tidak dapat dilakukan. ${ }^{4,5}$

Panjang tulang ulna telah terbukti reliabel dan presisi dalam memprediksi tinggi badan seseorang pada penelitian yang dilakukan di Amerika, Eropa, India dan Thailand. Penggunaan panjang tulang ulna dalam memprediksi tinggi badan di Eropa dan Amerika telah banyak dilakukan terutama dengan menggunakan tabel perhitungan baku. Penelitian tersebut juga menunjukkan panjang tulang ulna dipengaruhi oleh jenis kelamin. Akan tetapi dari penelitian tersebut terdapat perbedaan rumusan estimasi panjang tulang ulna terhadap tinggi badan karena perbedaan genetik, lingkungan, asupan gizi dan tempat pengambilan data. ${ }^{6-10}$
Pada penelitian sebelumnya didapatkan banyak rumus, akan tetapi tidak semua rumus menggunakan ulna lengan kiri dan membedakan rumus berdasarkan jenis kelamin. Penelitian sebelumnya menggunakan subjek dengan rentang usia yang beragam, dalam penelitian ini usia subjek yang diambil adalah 19 sampai 29 tahun karena mengacu pada usia dewasa aktif.

Estimasi tinggi badan yang umum dikenal dan telah diaplikasikan di Indonesia antara lain tinggi lutut dan panjang depa, metode estimasi dengan tulang ulna di Indonesia masih belum banyak dikenal oleh masyarakat dan praktisi kesehatan sehingga belum banyak diaplikasikan. Penelitian mengenai kesesuaian panjang tulang ulna dengan tinggi badan belum banyak dilakukan di Indonesia. Penelitian ini bertujuan untuk menganalisis perbedaan tinggi badan berdasarkan panjang tulang ulna dengan tinggi badan aktual. Selain itu penelitian ini dapat merusmukan tinggi badan dari tulang ulna yang tepat digunakan di Indonesia.

\section{METODE}

Penelitian ini dilakukan di kampus Universitas Diponegoro dan di kota Semarang pada bulan September 2013. Penelitian ini merupakan penelitian cross sectional. Jumlah subjek minimal pada penelitian ini sebesar 97 orang dan jumlah subjek yang dianalisis 103 orang yang terdiri dari 55 wanita dan 48 pria. Pengambilan data dilakukan di kampus Universitas Diponegoro pukul 12.00 WIB dan dalam acara Car Free Day kota Semarang pukul 07.30 WIB. Data yang diambil yaitu data karakteristik subjek, tinggi badan dan panjang ulna. Subjek penelitian diambil secara consequtive sample yang diberikan informed consent secara verbal. Kriteria inklusi antara lain pria dan wanita usia $19-29$ tahun, bersedia menjadi subjek dalam penelitian, dalam keadaan sehat, dapat diajak berkomunikasi, dapat berdiri tegak serta tidak memiliki kelainan (cacat) pada kedua lengan, kaki, dan tulang belakang.

Data yang dikumpulkan meliputi data karakteristik subjek, tinggi badan dan panjang ulna. Data karateristik subjek meliputi nama, jenis kelamin, usia, alamat, nomor telepon dan asal daerah, diperoleh melalui wawancara oleh enumerator. Data tinggi badan subjek diperoleh 
dengan mengukur tinggi badan dari titik tertinggi kepala (cranium) yang disebut vertex ke titik terendah dari tulang kalkaneus yang disebut heel menggunakan microtoise kapasitas $200 \mathrm{~cm}$ ketelitian $0,1 \mathrm{~cm}$ dan data tinggi badan dilihat dua kali oleh enumerator yang berbeda. Data panjang tulang ulna subjek diperoleh dengan mengukur panjang tulang ulna dari lengan kiri dari ujung siku (prosesus olekranon) sampai pertengahan dari tulang yang menonjol di pergelangan tangan (prosesus stiloid) subjek menggunakan metlin/pita ukur kapasitas $150 \mathrm{~cm}$ ketelitian $0,1 \mathrm{~cm}$ dan data panjang ulna diukur dua kali oleh enumerator yang berbeda. Data tinggi badan dan panjang tulang ulna dicatat oleh enumerator pada formulir penelitian. Enumerator dalam penelitian ini adalah beberapa mahasiswa Ilmu Gizi angkatan 2009 yang telah dilatih sebelum pengambilan data dilaksanakan.

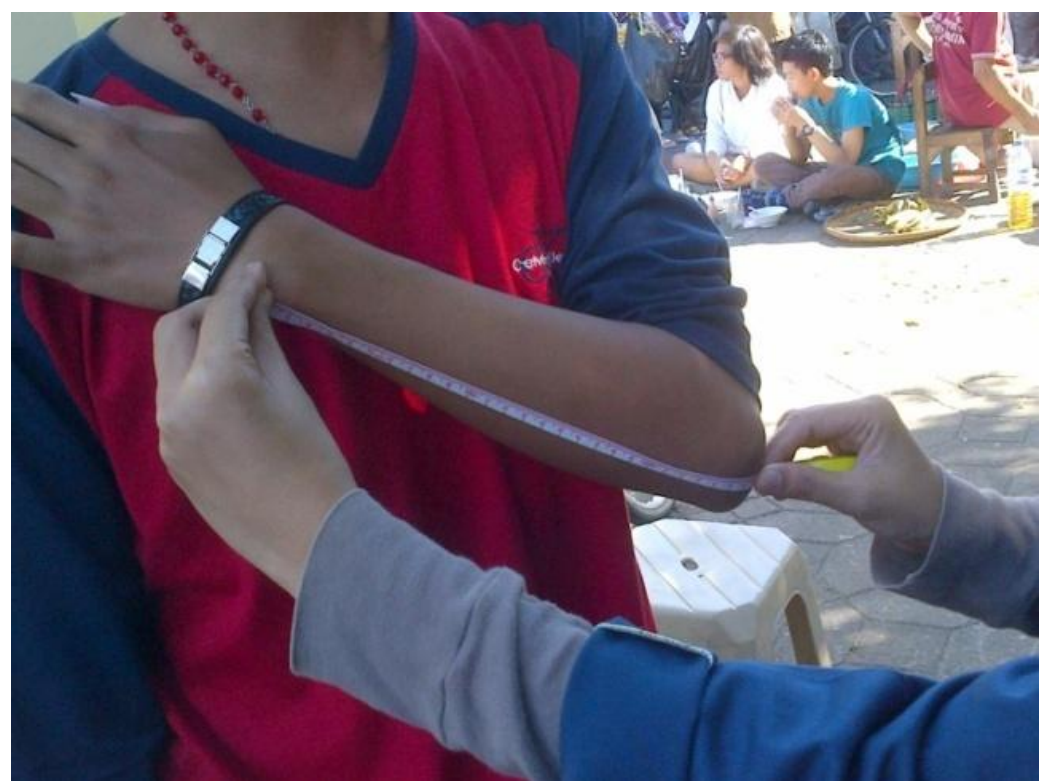

Gambar 1. Pengukuran panjang tulang ulna

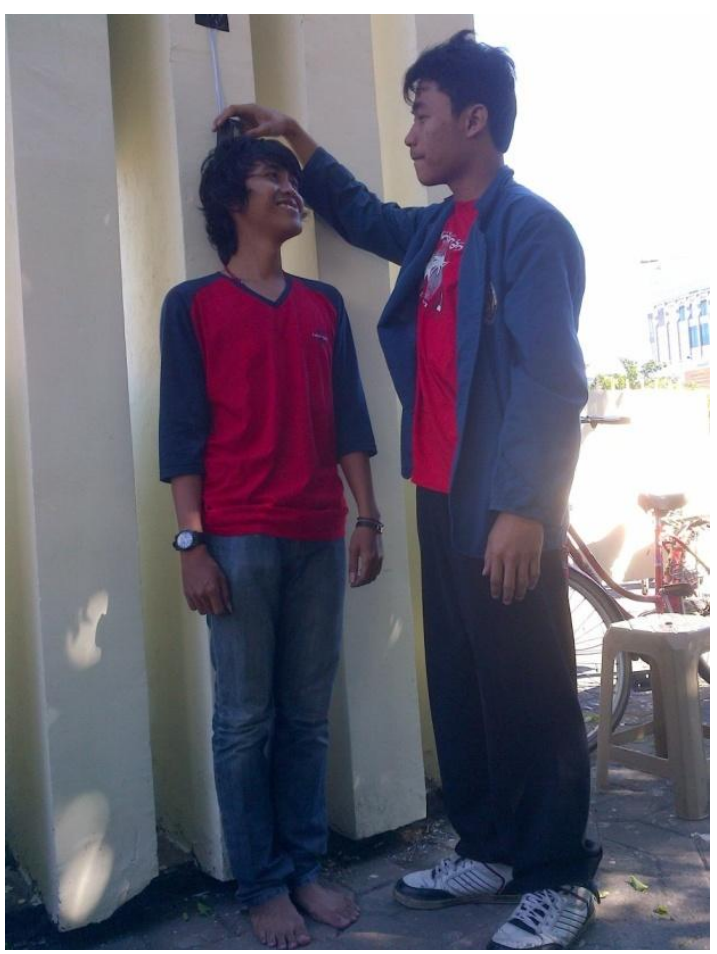

Gambar 2. Pengukuran Tinggi Badan 
Estimasi tinggi badan dari panjang ulna menggunakan rumus dari penelitian di India dan
Thailand karena karakteristik subjek antara India, Thailand dan Indonesia hampir sama. ${ }^{11}$

Tabel 1. Rumus Estimasi Tinggi Badan

\begin{tabular}{lcc}
\hline \multicolumn{1}{c}{ Pustaka } & Rumus Pria & Rumus Wanita \\
\hline $\begin{array}{l}\text { Rumus 1: Ilayperuma, } \\
\text { Nanayakkara, Palahepitiya } \\
(2010)^{12}\end{array}$ & $\begin{array}{c}97,252+2,645 \times \text { panjang } \\
\text { ulna }(\mathrm{cm})\end{array}$ & $\begin{array}{c}68,777+3,536 \times \text { panjang } \\
\text { ulna }(\mathrm{cm})\end{array}$ \\
\hline $\begin{array}{l}\text { Rumus 2: Thummar, Patel } \\
\text { Z, Patel S, Rathod (2011) }\end{array}$ & $\begin{array}{c}65,76+3,667 \times \text { panjang } \\
\text { ulna }(\mathrm{cm})\end{array}$ & $\begin{array}{c}18,95+5,33 \times \text { panjang ulna } \\
(\mathrm{cm})\end{array}$ \\
\hline $\begin{array}{l}\text { Rumus 3: Pureepatpong N, } \\
\text { Sangiampongsa A, }\end{array}$ & $\begin{array}{c}64,605+3,8089 \times \text { panjang } \\
\text { Lerdpipatworakul T, }\end{array}$ & $\begin{array}{c}66,377+3,5796 \times \text { panjang } \\
\text { ulna }(\mathrm{cm})\end{array}$ \\
Sangvichien S $(2012)^{9}$ & & (cm) \\
\hline
\end{tabular}

Analisis data dimulai dengan analisis deskriptif untuk mendeskripsikan karakteristik subjek. Kemudian dilakukan analisis bivariat yang diawali dengan uji normalitas data dengan uji Kolmogorov-Smirnov, didapat bahwa data berdistribusi tidak normal, telah dilakukan transformasi data dan data tetap berdostribusi tidak normal. Karena data berdistribusi tidak normal maka analisis dilanjutkan dengan uji beda MannWhitney untuk melihat perbedaan antar variabel.

\section{HASIL PENELITIAN \\ Karakteristik Subjek Penelitian}

tabel 2.

Tabel 2. Karakteristik subjek penelitian

\begin{tabular}{lllllll}
\hline \multirow{2}{*}{ Karakteristik Subjek } & \multicolumn{3}{c}{ Pria } & \multicolumn{3}{c}{ Wanita } \\
\cline { 2 - 7 } & Rerata \pm SB & Min & Max & Rerata \pm SB & Min & Max \\
\hline Usia & $21,75 \pm 2,61$ & 19,00 & 29,00 & $20,87 \pm 1,82$ & 19,00 & 27,00 \\
\hline
\end{tabular}

*Uji Descrptive

Rerata usia subjek pria adalah 21,75 tahun, usia minimal 19 tahun dan usia maksimal 29 tahun. Rerata usia subjek wanita adalah 20,87 tahun, usia minimal 19 tahun dan usia maksimal 27 tahun.

\section{Data Hasil Penelitian}

Data hasil penelitian disajikan pada tabel 3.

Tabel 3. Data hasil penelitian

\begin{tabular}{|c|c|c|c|c|c|c|c|c|}
\hline \multirow{2}{*}{\multicolumn{3}{|c|}{ Karakteristik subjek }} & \multicolumn{3}{|c|}{ Pria } & \multicolumn{3}{|c|}{ Wanita } \\
\hline & & & Rerata \pm SB & Min & $\operatorname{Max}$ & Rerata \pm SB & Min & Max \\
\hline \multirow{2}{*}{\multicolumn{3}{|c|}{ Tinggi }} & $\mathrm{I} 67,9 \pm 6,97$ & 152,30 & 185,00 & $156,9 \pm 5,92$ & 146,30 & 171,60 \\
\hline & & & $26,9 \pm 1,62$ & 23,50 & 32,75 & $24,7 \pm 1,37$ & 22,00 & 26,90 \\
\hline \multicolumn{3}{|c|}{ Panjang Ulna $(\mathrm{cm})$} & $168,24 \pm$ & 159,41 & 183,88 & $157,77 \pm$ & 148,77 & 166,59 \\
\hline \multirow{2}{*}{$\begin{array}{l}\text { Tinggi } \\
(\mathrm{cm})\end{array}$} & Badan & Rumus 1 & 5,77 & 151,93 & 185,85 & 5,51 & 136,21 & 162,33 \\
\hline & & & $166,28 \pm$ & 154,11 & 189,35 & $153,79 \pm$ & 145,13 & 162,67 \\
\hline \multirow{2}{*}{$\begin{array}{l}\text { Tinggi } \\
\text { (cm) }\end{array}$} & Badan & Rumus 2 & 6,65 & & & 7,32 & & \\
\hline & & & $167,61 \pm$ & & & $155,88 \pm$ & & \\
\hline $\begin{array}{l}\text { Tinggi } \\
\text { (cm) }\end{array}$ & Badan & Rumus & 6,56 & & & 5,51 & & \\
\hline
\end{tabular}

*Uji Descriptive

Tabel 3 menunjukkan bahwa perbedaan antara rerata tinggi badan aktual dengan estimasi tinggi badan dari rumus 1 , rumus 2 dan rumus 3 berturut-turut yaitu untuk pria $0,7 \mathrm{~cm}, 3,2 \mathrm{~cm}$, dan $0,6 \mathrm{~cm}$ sedangkan pada wanita $1,7 \mathrm{~cm}, 6,2 \mathrm{~cm}$, dan $2,1 \mathrm{~cm}$. 


\section{Perbedaan antara Estimasi Tinggi Badan dari Panjang Ulna Tinggi Badan Aktual dengan pada Pria dan Wanita}

Perbedaan antara tinggi badan aktual dengan estimasi tinggi badan dari panjang ulna pada pria dan wanita disajikan pada tabel 4.

Tabel 4. Perbedaan antara tinggi badan aktual dengan estimasi tinggi badan dari panjang ulna pada pria dan wanita

\begin{tabular}{|c|c|c|c|c|}
\hline \multirow{2}{*}{ Estimasi tinggi badan } & \multicolumn{2}{|l|}{ Pria } & \multicolumn{2}{|c|}{ Wanita } \\
\hline & Rerata \pm SB & Nilai $p$ & Rerata \pm SB & Nilai $p$ \\
\hline Rumus 1 (Ilayperuma et al $^{12}$ ) & $168,24 \pm 5,77$ & 0,464 & $157,77 \pm$ & 0,105 \\
\hline & $166,28 \pm 6,65$ & 0,011 & 5,51 & 0,000 \\
\hline Rumus 2 (Thummar et $\mathrm{al}^{13}$ ) $\mathrm{cm}$ & $167,61 \pm 6,56$ & 0,618 & $153,79 \pm$ & 0,094 \\
\hline Rumus 3 (Pureepatpong et $\mathrm{al}^{9}$ ) & & & 7,32 & \\
\hline $\mathrm{cm}$ & & & $\begin{array}{c}155,88 \pm \\
5,51\end{array}$ & \\
\hline
\end{tabular}

*Uji Mann-Whitney $(p<0,05)$

Tabel 4 menunjukkan bahwa tidak ada perbedaan antara tinggi badan aktual dengan estimasi tinggi badan dari panjang ulna rumus Ilayperuma et $\mathrm{al}^{12} \&$ rumus Pureepatpong et $\mathrm{al}^{9}$ pada pria dan wanita $(\mathrm{p}>0,05)$ dan ada perbedaan antara tinggi badan aktual dengan estimasi tinggi badan dari panjang ulna rumus Thummar et $\mathrm{al}^{13}$ pada pria dan wanita $(\mathrm{p}<0,05)$.

\section{Selisih Beda antara Ketiga Rumus dengan} Tinggi Badan Aktual

Tabel 5. Selisih Beda antara Ketiga Rumus dengan Tinggi Badan Aktual

\begin{tabular}{lcccccc}
\hline \multirow{2}{*}{ Estimasi Tinggi Badan } & \multicolumn{3}{c}{ Pria } & \multicolumn{4}{c}{ Wanita } \\
\cline { 2 - 7 } & Rerata \pm & \multirow{2}{*}{ Min } & \multirow{2}{*}{ Max } & Rerata \pm & SB & \multirow{2}{*}{ Max } \\
\hline Rumus 1 (Ilayperuma et $\mathrm{al}^{12}$ ) & $0,35 \pm 3,13$ & $-13,07$ & 11,08 & $0,86 \pm 3,14$ & $-12,82$ & 8,88 \\
Rumus 2 (Thummar et $\mathrm{al}^{13}$ ) & $-1,62 \pm$ & $-16,86$ & 5,13 & $-3,12 \pm$ & $-23,09$ & 3,26 \\
Rumus 3 (Pureepatpong et & 3,42 & $-14,17$ & 7,53 & 4,85 & $-16,54$ & 5,00 \\
$\mathrm{al}^{9}$ ) & $-0,28 \pm$ & & & $-1,04 \pm$ & & \\
& 3,04 & & & 3,19 & & \\
\hline
\end{tabular}

\section{*Uji Descriptive}

Tabel 5 menunjukkan bahwa pada pria dan wanita terdapat selisih rerata yang kecil antara tinggi badan aktual dengan estimasi tinggi badan ketiga rumus. Akan tetapi terdapat selisih jangkauan yang besar antara tinggi badan aktual dengan estimasi tinggi badan ketiga rumus.

\section{PEMBAHASAN}

Pengukuran tinggi badan sangat penting untuk perhitungan indeks massa tubuh yang sering digunakan sebagai variabel pengkajian gizi. $^{13,14}$ Pasien di rumah sakit sebagian besar dalam keadaan tidak dapat berdiri tegak untuk diukur tinggi badannya. Oleh karena itu, formula dari panjang tulang ulna dapat menjadi alternatif estimasi tinggi badan dalam keadaan tertentu. Panjang ulna dapat secara mudah diukur saat alat gerak tubuh bagian bawah mengalami cedera atau patah tulang yang parah. ${ }^{12}$
Rerata usia subjek penelitian ini yaitu pria 21,75 tahun dan rerata usia subjek wanita 20,87 bila dibandingkan dengan penelitian sebelumnya di Sri Lanka yaitu rerata pria 21,03 tahun dan wanita 21,27 rerata usia hampir sama. Jumlah subjek dalam penelitian ini adalah 103 orang yaitu 48 pria dan 55 wanita bila dibandingkan dengan penelitian sebelumnya yang mengambil subjek 258, 310, dan 275 orang, jumlah subjek dalam penelitian ini lebih kecil karena populasinya terbatas untuk kota Semarang saja

Rerata tinggi badan dalam penelitian ini yaitu pria $167,9 \mathrm{~cm}$ dan rerata tinggi badan wanita $156,9 \mathrm{~cm}$, bila dibandingkan dengan subjek peneltian sebelumnya yaitu di Sri Lanka rerata tinggi badan pria $170,14 \mathrm{~cm}$ dan rerata tinggi badan wanita $157,55 \mathrm{~cm}$, rerata tinggi badan pria dalam penelitian ini lebih pendek $2,24 \mathrm{~cm}$ dan wanita lebih pendek $0,65 \mathrm{~cm}$. Rerata panjang ulna dalam penelitian ini yaitu pada pria $26,9 \mathrm{~cm}$ dan 
pada wanita $24,7 \mathrm{~cm}$, bila dibandingkan dengan subjek penelitian sebelumnya di Sri Lanka rerata panjang ulna yaitu pada pria $27,56 \mathrm{~cm}$ dan pada wanita $25,11 \mathrm{~cm}$, rerata panjang ulna pria dalam penelitian ini lebih pendek $0,66 \mathrm{~cm}$ dan wanita lebih pendek $0,41 \mathrm{~cm}$. Rerata hasil estimasi tinggi badan pada pria dari tulang ulna pada pada ketiga rumus yaitu berturut-turut $168,6 \mathrm{~cm}, 164,7 \mathrm{~cm}$, dan $167,3 \mathrm{~cm}$.

Perbedaan rerata estimasi tinggi badan dari ketiga rumus dengan tinggi badan aktual berturut-turut adalah $+0,7 \mathrm{~cm},-3,3 \mathrm{~cm}$, dan $+0,6$ $\mathrm{cm}$ yang secara statistik rumus Ilayperuma et $\mathrm{al}^{10}$ dan Pureepatpong et $\mathrm{al}^{9}$ tidak ada perbedaan $(p=0,464 \& p=0,618)$. Secara statistik terdapat perbedaan estimasi tinggi badan dari rumus Thummar et $\mathrm{al}^{11}$ dengan tinggi badan aktual $(\mathrm{p}=0,011)$ sehingga rumus ini tidak dapat diterapkan di Indonesia. Rerata hasil estimasi tinggi badan pada wanita dari tulang ulna pada pada ketiga rumus yaitu berturut-turut $158,6 \mathrm{~cm}$, $150,7 \mathrm{~cm}$, dan $154,8 \mathrm{~cm}$. Perbedaan rerata estimasi tinggi badan dari ketiga rumus dengan tinggi badan aktual berturut-turut adalah $+1,7 \mathrm{~cm},-6,2 \mathrm{~cm}$, dan $+2,1 \mathrm{~cm}$ yang secara statistik rumus Ilayperuma et $\mathrm{al}^{10}$ dan Pureepatpong et $\mathrm{al}^{9}$ tidak ada perbedaan $(p=0,105 \& p=0,094)$. Secara statistik terdapat perbedaan estimasi tinggi badan dari rumus Thummar et $\mathrm{al}^{11}$ dengan tinggi badan aktual $(\mathrm{p}=0,000)$ sehingga rumus ini tidak dapat diterapkan di Semarang.

Penelitian yang menghasilkan rumus Thummar et $\mathrm{al}^{11}$ dan Pureepatpong et $\mathrm{al}^{9}$ bertujuan mencari rumusan spesifik untuk populasi di Gujarat dan Thailand sedangkan penelitian yang menghasilkan rumus Ilayperuma et $\mathrm{al}^{10}$ bertujuan untuk mencari rumusan yang tepat untuk populasi di Sri lanka dan Asia Selatan secara umum. Penelitian Thummar et $\mathrm{al}^{11}$ mengambil subjek dengan rentang usia antara 20 - 40 tahun yang lebih luas bila dibandingkan dengan rentang usia pada penelitian ini dan termasuk dalam kategori dewasa kelompok pertama dan kedua. Tinggi badan secara progresif menurun seiring dengan bertambahnya usia karena penyusutan urat-urat tulang belakang ${ }^{15}$, sehingga mungkin dalam penelitian rumus Thummar et $\mathrm{al}^{9}$ terdapat beberapa subjek yang telah mengalami penurunan tinggi badan karena bertambahnya usia dan mungkin karesteristik subjek yang berbeda dengan karakteristik subjek pada penelitian ini karena rumus estimasi tulang ulna spesifik untuk populasi tertentu $^{16}$. Serta bila dilihat dengan seksama, terdapat perbedaan rumus wanita Thummar et al ${ }^{11}$ dengan dua rumus lainnya.

Nilai selisih rerata antara estimasi tinggi badan dengan tinggi badan aktual penelitian yang dilakukan di Turki yaitu $0,21 \mathrm{~cm}$ dengan standar deviasi 7,24 , nilai maksimum $11,74 \mathrm{~cm}$ dan nilai minimum $-20,71 \mathrm{~cm}^{16}$. Selisih beda antara estimasi tinggi badan dengan tinggi badan aktual pria pada penelitian ini yaitu dari rumus Ilayperuma et $\mathrm{al}^{10}$ rerata $0,35 \mathrm{~cm}$; rumus Thummar et al ${ }^{11}$ yaitu nilai rerata $-1,62 \mathrm{~cm}$; dan rumus Pureepatpong et $\mathrm{al}^{9}$ yaitu nilai rerata $-0,28 \mathrm{~cm}$. Sedangkan selisih estimasi tinggi badan dengan tinggi badan aktual wanita pada penelitian ini dari rumus Ilayperuma et $\mathrm{al}^{10}$ yaitu nilai rerata $0,86 \mathrm{~cm}$; rumus Thummar et $\mathrm{al}^{11}$ yaitu nilai rerata $-3,12 \mathrm{~cm}$; dan rumus Pureepatpong et $\mathrm{al}^{9}$ yaitu nilai rerata $-1,04 \mathrm{~cm}$. Pada penelitian yang dilakukan di Jakarta dan Malaysia, suatu formula dapat dikatakan berbeda jika nilai $\mathrm{p}<0,05$ dan perhitungan statistik menggunakan rerata. ${ }^{17-19}$

Penerapan rumus regresi harus hati-hati pada populasi berbeda karena rumus regresi Pearson diturunkan untuk populasi tertentu. Pada tahun 1929, sebuah penelitian membenarkan adanya perbedaan antar populasi sehubungan dengan estimasi tinggi badan, sejak saat itu kebanyakan penelitian menekankan bahwa rumus regresi untuk estimasi tinggi badan harus digunakan untuk populasi spesifik. ${ }^{14,20}$ Rumus yang digunakan dalam penelitian ini yaitu rumus Ilayperuma et $\mathrm{al}^{10}$ : pria $=97,252+2,645 \mathrm{x}$ panjang ulna dan wanita $=68,777+3,536 \times$ panjang ulna; Thummar et al $^{11}$ : pria $=65,76+3,667 \times$ panjang ulna dan wanita $=18,95+5,33 \times$ panjang ulna; dan Pureepatpong et $\mathrm{al}^{9}$ : pria $=64,605+3,8089 \mathrm{x}$ panjang ulna dan wanita $=66,377+3,5796 \quad x$ panjang ulna.

Banyak metode untuk memprediksi tinggi badan dari tulang panjang, akan tetapi metode analisis regresi secara nyata merupakan metode paling mudah dan reliabel ${ }^{10}$. Rumus regresi untuk memprediksi tinggi badan diformulasikan dari tinggi badan dan panjang ulna subjek yang diteliti. Penelitian di Sri Lanka, Mauritian, Gujarat, Nigeria, Marathwada, Burdwan, dan Thailand menunjukkan hasil yang sama dan dapat menjadi alternatif estimasi tinggi badan tiap-tiap populasi yang diteliti. ${ }^{6-13}$

Karakteristik yang mempengaruhi tumbuh kembang manusia antara lain usia, ras, gender dan status gizi. Oleh karena itu, tiap populasi memiliki karakteristik yang berbeda dan formula yang dihasilkan spesifik untuk populasi tertentu ${ }^{10,21}$. 
Penelitian ini menghasilkan formula regresi linier dari tinggi badan dan panjang ulna subjek, yaitu untuk pria $=76,053+3,405 \times$ ulna lengan kiri; untuk wanita $=81,927+3,034 \times$ ulna lengan kiri; untuk semua kasus $=63,208+3,836 \times$ ulna lengan kiri. Penelitian ini merupakan penelitian yang mengambil subjek pria dan wanita usia 19 sampai 29 tahun di Kota Semarang sehingga formula yang didapat mungkin direkomendasikan untuk rentang usia dan populasi yang hampir sama.

\section{SIMPULAN}

Tidak ada perbedaan antara tinggi badan aktual dengan tinggi badan dari panjang ulna pada rumus Ilayperuma et $\mathrm{al}^{10}$ dan Pureepatpong et $\mathrm{al}^{9}$ terdapat perbedaan antara tinggi badan aktual dengan tinggi badan dari panjang ulna pada rumus Thummar et $\mathrm{al}^{11}$.

\section{SARAN}

Praktisi kesehatan di rumah sakit dapat menggunakan panjang ulna sebagai estimasi tinggi badan pasien yang tidak dapat berdiri, tidak memungkin diukur tinggi lutut dan panjang depanya.

\section{DAFTAR PUSTAKA}

1. Mayer BH, Tucker L, Williams S, Dwijayanthi L, Nugroho AW, Santoso N. Ilmu Gizi Menjadi Sangat Mudah. Edition Kedua. Jakarta: Penerbit Buku Kedokteran EGC. 2007 (1)

2. Freitag E, Edgecombe G, Baldwin I, Cottier B, Heland M. Determination of body weight and height measeurement for critically ill patients admitted to the intensive care unit: a quality improvement project. [serial online]. 2010. Diakses dari:

http://www.sciencedirect.com/science/article/pi i/S1036731410000792.pdf

3. Geurden B, Franck E, Weyler E, Weyler J, Ysebaert D. Nurses Estimating body weight and height to screen for malnutrion in bedridden patients: good practice [serial online]. 2011. Diakses dari: http://www.sciencedirect.com/science/article/pi i/S1751499111000424.pdf

4. Gambaran Pelayanan Gizi Rawat Inap di Rumah Sakit Umum Menteng Mitra Afia Cikini Jakarta Pusat [serial online]. 2009. Diakses dari: http://perpus.fkik.uinjkt.ac.id/file_digital/BAGI AN\%20PERTAMA_NURDIANA\%20HAJAR $\% 20 . p d f$

5. Berg VDL, Dannhauser A, Nel M. Agreement between Estimated and Measured heights and weights in hospitalized patients - a retrospective study [serial online]. 2010. Diakses dari https://www.google.com/url?sa=t\&rct=j\&q=\& esrc $=$ s\&source $=$ web $\& c d=6 \& c a d=r j a \& v e d=0 \mathrm{C}$ FsQFjAF\&url=http $\% 3 \mathrm{~A} \% 2 \mathrm{~F} \% 2 \mathrm{Fwww}$.ajol.inf o\%2Findex.php\%2Fsajen\%2Farticle\%2Fdown load\%2F52782\%2F41384\&ei=7fO2UZ6nMJG qrAfx04HYAQ\&usg=AFQjCNFqjc3AtseWlO ENNNmMyinX7foFfQ\&sig2=wvdIGK_nbJ5iz xnMlL_kFw\&bvm=bv.47534661,d.bmk

6. Ebite LE. Ozoko TC. Eweka AO. Otuaga PO. Height: Ulna Ratio: A Method of Stature Estimation In A Rural Community In Edo State, Nigeria. 2008. The International Journal of Forensic Science, 3(1). Diakses dari www.archieve.ispub.com

7. Gauld LM, Kappers J. Carlin JB. Robertson CF. Height Prediction from ulna length. 2004. Dev. Med. Child Neurol., 46(7):475-80. Diakses dari www.biomedscidirect.com

8. Prasad A, Bhagwat B, Porwal S, Joshi S. Estimation of Human Stature from length of Ulna in Marathwada Region of Maharashtra [serial online]. 2012. (dikutip pada tanggal 4 Juni 2013). Diakses dari http://www.biomedscidirect.com/science/articl e/IJBMRF2012970.pdf

9. Pureepatpong N, Sangiampongsa A, Lerdpipatwoerakul T, Sangvichien S. Stature Estimation of Modern Thais from Long Bones: A Cadaveric Study [serial online]. 2012. (dikutip pada tanggal 12 Juni 2013). Diakses dari http://www.sirirajmedj.com

10. Malnutrition Advisory Group. The "MUST" explanatory booklet. British Association for Parenteral and Enteral Nutrition. Diakses dari: http://www.bapen.org.uk/the-must.htm

11. Olson S. Mapping Human History: Discovering the Past Through Our Genes (terjemahan). Jakarta: PT. Serambi Ilmu Semesta. 2006.2 (e-book). http://books.google.co.id/books?id=tdRSd1qb9 QsC\&pg=PA188\&dq=antropologi+budaya $+:+r$ as+mongoloid\&hl=id\&sa $=$ X\&ei $=0900 U$ sveC MitrAfJ-

4HoDg\&ved=0CEgQ6AEwBg\#v=onepage \&q $=$ antropologi $\% 20$ budaya $\% 20 \% 3 \mathrm{~A} \% 20 \mathrm{ras} \% 20$ mongoloid\&f=false

12. Ilayperuma I, Nanayakkara G, Palahepitiya N. A Model for the Estimation of Personal Stature from the Length of Forearm [serial online]. Int. J. Morphol. 2010. Diakses dari: http://www.scielo.cl/pdf/ijmorphol/v28n4/art15 .pdf

13. Thummar B, Patel ZK, Patel S, Rathod SP. Measurement of Ulnar Length for Estimation of Stature in Gujarat [serial online]. 2011. (dikutip pada tanggal 15 Mei 2013). Diakses 
dari:

http://www.scopemed.org/fulltextpdf.php?mno

$=8709$

14. Joshi NB, Patel MP, Dongre AV. Regression Equation of Height from Ulna Length. Ind. J. Med. Res. 1964. Diakses dari: http://www.ncbi.nlm.nih.gov/pubmed/1425223 9

15. William PL, Bannister LH, Berry MM, Collins P, Dyson M, Dussek JE, Gray's Anatomy: The Anatomical Basis of Medicine and Surgery. $38^{\text {th }}$ edition. New York: Churchill Livingstone. 2000.

16. Duyar I, Pelin C. Estimating Body Height from Ulna Length: Need of a Population-Spesific Formula. Eruasian J. Anthropol. 1(1):11-17. 2010.

http://www.eurasianjournals.com/index.php/eja /article/viewFile/327/485

17. Salim Ch O, Kusumaratna RK, Sudharma NI, Hidayat A. Tinggi Lutut sebagai Prediktor dari Tinggi Badan pada Lanjut Usia. Universa Medicina. 2006 [serial online]. Diakses dari: http://www.univmed.org/wpcontent/uploads/2012/04/dr-oktav-dkk.pdf

18. Fatmah. Persamaan (Equation) Tinggi Badan Manusia Usia Lanjut (Manula) Berdasarkan Usia dan Etnis pada 6 Panti Terpilih di DKI Jakarta dan Tangerang Tahun 2005 [serial online]. Diakses dari:

http://journal.ui.ac.id/index.php/health/article/d ownload/145/141.pdf

19. Shahar S, Pooy NS. Predictive Equations for Estimation of Stature in Malaysian Elderly People. Asia Pasific J Clinical Nutrition. 2003. Diakses dari: http://apjcn.nhri.org.tw/server/apjcn/12/1/80.pd f

20. Agnihotri AK, Kachhwaha S, Jowaheer V, Sigh AP. Estimaing Stature from Percutaneous Length of Tibia and Ulna in Indo-Mauritian Population [serial online]. 2009. (dikutip pada tanggal 17 November 2013). Diakses dari http://www.elsevier.com/locate/forsciint

21. Krogman WM, Iscan MY. The Human Skeleton in Forensic Medicine. $\left(2^{\text {nd }}\right.$ ed). Springfield: Charles C Thomas. 1986. 